\title{
Interaction between Liposomal Membrane and Sodium Dodecyl Sulfate as Studied by an ESR Spin Probe Method
}

\author{
Masahiro FuKudA, Masako Fujitsu, and Kazuo OHBU \\ Applied Research Laboratories II, Lion Corporation (7-13-12, Hirai, \\ Edogawa-ku, Tokyo $\mathbf{T} 132$ )
}

\begin{abstract}
Interactions between phospholipid liposomal membranes and sodiumdodcyl sulfate in a phosphate buffer solution $(50 \mathrm{mM}, \mathrm{pH} 7$ ) were studied by the ESR spin probe, 2-(3-carboxypropyl)-4,4-di= methyl-2-tridecyl-1,3-oxazolidin-3-oxyl. Sodium dodecyl sulfate molecules ( $2 \mathrm{mM}$ ) incorporated into phospholipid bilayers $(13.6 \mathrm{mM}$ ) appeared to form clusters by themselves, causing phase separation of the bilayers. The possibility of two distict liposomes, one phospholipid-rich and the other, SDSrich, was excluded on the basis of results obtained by a centrifugal experiment under the above conditions.
\end{abstract}

\section{Introduction}

Liposomes are now being developed as drug carriers $^{1)}$. The interaction of surfactant mo= lecules with liposomes has been extensively investigated with regard to the leakage of the contents encapusulated in the interior of lipo= somes. Also, liposomes are widely used as biomembrane models ${ }^{2}$. One of the actions of anaesthetics on the biomembrane can be cor $=$ related with a change in the fluidity of the biomembrane ${ }^{3)}$. In order to clarify the action of anaesthetics, it is very important to inves= tigate the fundamental interaction of anaes= thetics with biomembranes and the influences of fluidity on them. It seems advantageous to use surfactants as anaesthetic models because their use enables the control of the amphi= philicity by changing their alkyl chain lengths. Hence, understanding of the interaction be= tween model biomembranes and surfactants is important ${ }^{4)}$.

We will report, in the first phase of our experiments, that the influence of sodium do= decyl sulfate (SDS) on the fluidity of the phospholipid bilayers was investigated using a spin labelled stearic acid.

\section{Experimental}

Materials : $L-\beta, \gamma$-Dipalmitoyl $-\alpha$-phospha $=$ tidylcholine (DPPC) was purchased from Fluka
AG. L- $\alpha$-phosphatidylcholine from frozen egg yolk (type VII-E), 2-(3-carboxypropyl)-4, 4-di= methyl-2-tridecyl-1, 3-oxazolidin-3-oxyl (5NS), 2-(10-carboxydecyl) -2-hexyl-4, 4-dimethyl-1, 3oxazolidin-3-oxyl (12NS), and 2-(14-carboxy= tetradecyl)-2-ethyl-4, 4-dimethyl-1, 3-oxazolid = in-3-oxyl (16 NS) were obtained from the Sigma Chemical Company and used without further purification.

Preparation of Liposomes: Multilayered liposomes were prepared according to the method of Bangham et $a l^{5)}$. Evaporating the mixture of $100 \mu \mathrm{L}$ of chloroform solution cono taining the phospholipid (13.6 $4 \mathrm{~mol}$ ) and 0.7 $\mathrm{mL}$ of ethanol solution containing a spin probe $(0.14 \mu \mathrm{mol})$ so that the mixture of the phos= pholipid and spin probe molecules dried as a thin film on the surface of the flask. One mililiter of the surfactant solution containing $50 \mathrm{mM}$ phosphate buffer ( $\mathrm{pH} 7)$ was poured into the flask. The final concentration of the phospholipid was $13.6 \mathrm{mM}$. The dispersion of phospholipid was carried out by shaking on a Vortex mixer at a temperature of about $30^{\circ} \mathrm{C}$ higher than the phase transition tempe $=$ rature of the phospholipid being used.

ESR Measurement : The molar ratio of spin probes to phospholipids was about 1 : 100. The liposome suspension was drawn up in a $1 \mathrm{~mm} \mathrm{o.d.} \mathrm{capillary} \mathrm{tube} \mathrm{in} \mathrm{the} \mathrm{presence}$ of air. ESR spectra were recorded at $50^{\circ} \mathrm{C}$ on 
a Japan Electron Optics Laboratory Model JES-1 X spectrometer with $100 \mathrm{kHz}-0.63$ gauss modulation. The order parameter, designated as $S$, was estimated from the spectra. The quantity of $S$ was defined by

$$
\begin{gathered}
S=3 / 2 \times\left(\mathrm{A}_{\prime \prime}-\mathrm{a}_{\mathrm{N}}\right) /\left(\mathrm{A}_{z z}-\right. \\
\left.\left(\mathrm{A}_{\mathrm{xx}}+\mathrm{A}_{\mathrm{yy}}\right) / 2\right)
\end{gathered}
$$

where $A_{1}$ is the parallel components of the hyperfine splitting. $A_{x x}, A_{y y}, A_{z z}$ are assumed to be $6.3,5.8$, and 33.6 gauss, respectively ${ }^{6)}$. The value of $a_{N}$ is defined by

$$
a_{N}=\left(A_{x x}+A_{y y}+A_{z z}\right) / 3
$$

Therefore, the experimental value of $A_{\text {" }}$ yields the $S$ value.

Centrifugation : Aliquots of the disper= sions were spun at $430 \mathrm{~g}$ for $10 \mathrm{~min}$ in a Hitachi 05 PR-22 rotor. The clear supernatant was removed by decantation and used in the ESR experiments.

\section{Results and Discussion}

Suspensions of DPPC liposomes and egg yolk lecitin liposomes containing $5 \mathrm{NS}$ and various amounts of SDS were prepared. When the ESR spectra for DPPC liposomes were measured at room temperature, the obtained spectra were composed of superposed spectra provided by partitioning of $5 \mathrm{NS}$ between the aqueous phase and the lipid phase of the liposomes. The former gave rise to three sharp resonance lines and the latter gave magnetically anisotropic and broad lines. In order to make the spectral analysis easier, these measurements were performed at $50^{\circ} \mathrm{C}$, a temperature that is higher than that of the phase transition of DPPC and egg yolk lecitin liposomes. The spectra for those liposomes without SDS were the well known patterns as illustrated in Figs.-1 (a) and 2 (a). The $S$ values for DPPC and egg yolk lecitin were 0.51 and 0.52 , respectively. Since the examined tem $=$ perature was well above the phase transition temperature, both calculated order parameters are very close to each other.

Under such a condition that the molar ratio of SDS to phospholipid is well below zero point five, the spectra obtained in the presence of SDS can be interpreted as a superposition of two different configurations of the $5 \mathrm{NS}$ molecules. Namely, as shown in Fig. -1 (c), signal $\mathbf{A}$, indicated by arrow $\mathbf{A}$, comes from the rather extended form of $5 \mathrm{NS}$ and signal $\mathbf{B}$ is due to a folded configuration ${ }^{6)}$. A folding of the $5 \mathrm{NS}$ hydrocarbon chain means a fast rotational isomerization between the trans and gauche conformations indicating the circumst= ances around this probe are more fluid than those around the other probes with a signal $\mathbf{A}$.

The interaction between Triton X-100 and phosphatidylcholine liposomes was studied by Anzai et al., ${ }^{7)}$ they postulated from the analysis of the spectral change based on a spin-spin exchange broadening effect than, in some cases, heterogeneous mixing may occur on the lipo= somal membranes and that Triton-rich regions and phospholipid-rich regions are separated to some extent.

The spectra observed in this study directly show that the $5 \mathrm{NS}$ molecules are incorporated at the two different levels; one is phospho= lipid-rich regions and the other is SDS-rich regions. The component with the smaller $S$ value will correspond to a signal for $5 \mathrm{NS}$ localized in the SDS-rich regions. The intensity for the component with the smaller $S$ value became larger with increasing amounts of SDS as illustrated in Fig.-1. On the other hand, when the concentration of the liposomes was changed and the concentration of SDS was kept constant, the intensity of the component with the smaller $S$ value increased with de= creasing amounts of liposomes. (Data are not shown.) Such an observation is a similar relation to that described above. Under these conditions, the degree of the outer hyperfine splitting with the larger $S$ value did not change regardless of the concentration of SDS added. Hence, SDS molecules incorporated into the phospholipid bilayers are supposed to form clusters made up of large portions of the SDS molecules.

Alternatively, one could imagine that there exists two types of liposomes; one is phos= pholipid-rich and the other SDS-rich. In order to exclude this possibility, we exam= ined the additional ESR measurements. DPPC liposomes treated with $2 \mathrm{mM}$ of SDS solution were fractionated by centrifugation at $430 \times \mathrm{g}$ for $10 \mathrm{~min}$. The lower layer after centrifuging had a milky turbidity and almost all of the 

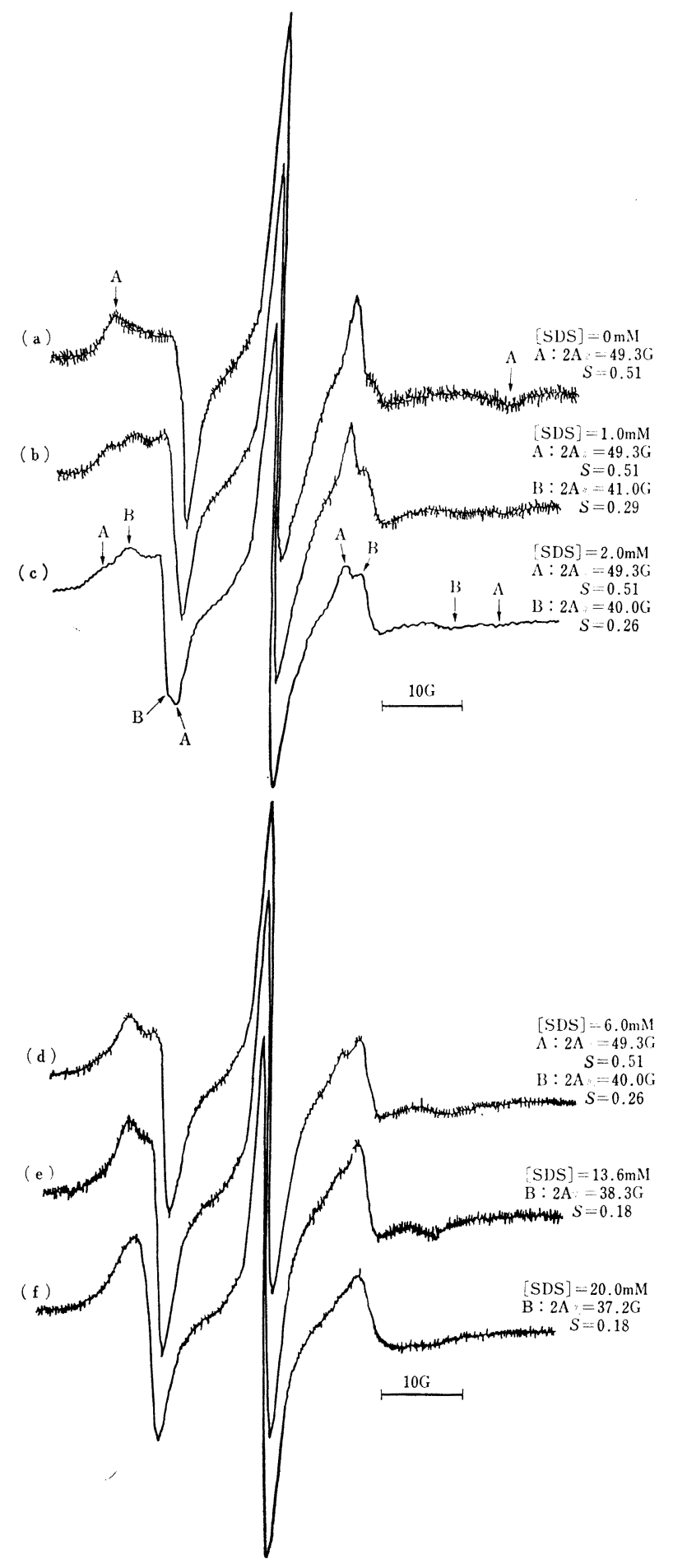

Fig.-1 ESR spectra of $5 \mathrm{NS}$ in the presence of DPPC liposomes in $50 \mathrm{mM}$ phosphate buffer (pH 7) measured at $50^{\circ} \mathrm{C}$. The concentration of DPPC was $13.6 \mu \mathrm{mol} / \mathrm{mL}$ and that of $\mathrm{SDS}$ is shown in the figure. Arrow $\mathbf{A}$ indicates a signal originated from the compo= nent with the larger $S$ value while arrow $\mathbf{B}$ indicates a signal from the component with the smaller $S$ value. The order parameter, $S$, was calculated using the equation described in the text. 


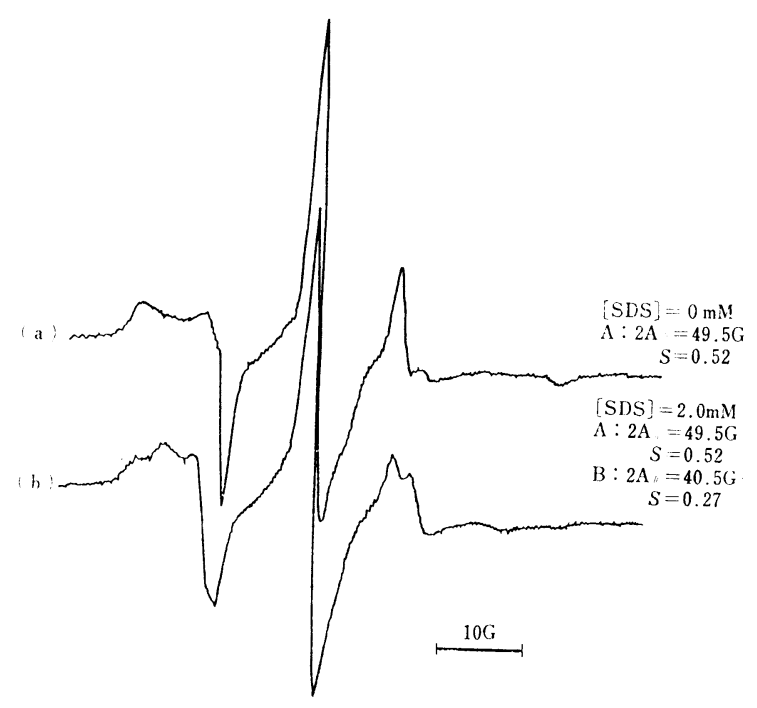

Fig.-2 ESR spectra of $5 \mathrm{NS}$ in the presence of egg yolk lecitin liposomes measured under the same conditions as described in Fig.-1.

liposomes were concentrated in this layer. The spectrum for this layer was similar to that before centrifuging as shown in Fig.-3. On the other hand, the appearance of the upper layer was almost transparent. This layer might contain rather small liposomes and/or SDS-phospholipid mixed micelles. How $=$ ever, the spectrum for the upper layer was the same as that before centrifuging. If such SDS-phospholipid mixed micelles are formed, the resonance lines observed should have been more isotropic. Therefore, SDS is presumed

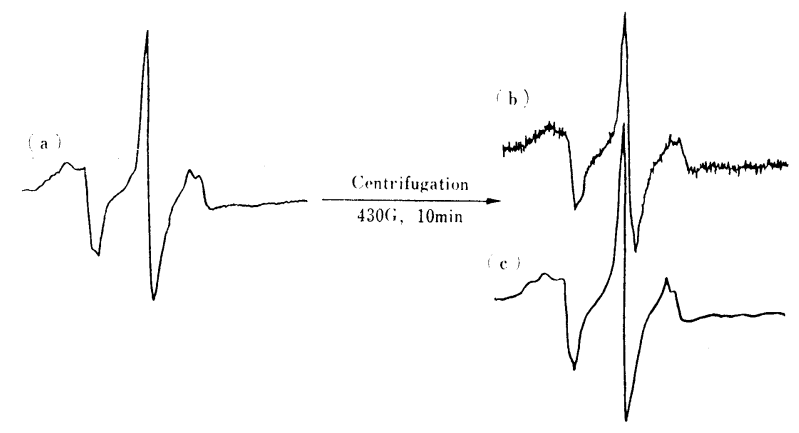

Fig.-3 ESR spectra of fractionated liposome sus= pensions. Spectrum (a) was obtained with $2 \mathrm{mM}$ SDS. Spectra (b) and (c) were ob= tained from the upper supernatant and the lower milky layer, respectively. The con= ditions for ESR measurements were the same as described in Fig. $\mathbf{1}$. to act in a manner so that the intrasegregation may take place on the liposomal membranes. Increasing the concentration of SDS above 6 $\mathrm{mM}$, the intensity of the outer peak A de= creased and the isotropic resonance lines were observed at $20 \mathrm{mM}$ of SDS, where the mixed micelles of SDS. and phospholipid may be formed.

Furthermore, the ESR measurements were done using the other spin probes. A spin probe of $12 \mathrm{NS}$ or $16 \mathrm{NS}$ gave rise to three symmetric resonance lines and the rotational correlation time, $\tau_{c}$, was calculared from the spectrum according to an equation described in the literature ${ }^{8)}$. For egg yolk lecitin lipo= somes, the value of $\tau_{\mathrm{c}}$ was $1 \times 10^{-9} \mathrm{~s}$ for 12 $\mathrm{NS}$ and $4 \times 10^{-10} \mathrm{~s}$ for $16 \mathrm{NS}$. In spite of adding $2 \mathrm{mM}$ of SDS, the value of $\tau_{c}$ was unchanged. This means that close to the polar regions of the bilayer the motion of the spin probe is highly anisotropic and influenced by added SDS molecules, but becomes more iso= tropic toward the bilayer interior and inde= pendent in the presence of SDS.

The last question to be answered was wheth= er a phase separation caused by SDS might result in the presence of $5 \mathrm{NS}$ molecules them= selves. SDS is an anionic surfactant and 5 NS is also anionic. In order to investigate the repulsion effect generated between the same charges of $5 \mathrm{NS}$ and SDS, a fatty acid was used in place of SDS. The spectrum obtained is the well known pattern as illus= trated in Fig.-4. No superposition was observed. Incorporated fatty acid mol=

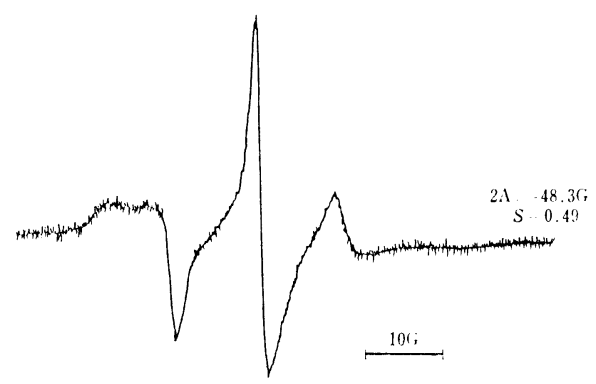

Fig.-4 ESR spectrum of $5 \mathrm{NS}$ in the presence of DPPC liposomes with $2 \mathrm{mM}$ sodium dodecanoate. The conditions for ESR mea= surements were the same as described in Fig. -1 . 
ecules may have a tendency to be evenly distributed in the bilayer. Thus, we speculated that the repulsion effect between $5 \mathrm{NS}$ mol= ecules and the anionic surfactant molecules is not responsible for the intrasegregation in the bilayer.

It can be concluded at this time that the interaction between phospholipid liposomes and SDS may cause the intrasegregation in the bilayer under such a condition that the molar ratio of SDS to phospholipid is well below zero point five and that the phase sep= aration can be observed using a labelled stearic acid, $5 \mathrm{NS}$, which has a doxyl radical moiety close to the polar head group.

(Received Jan. 24, 1987)

\section{References}

1) Y. Toyoshima and K. Kurihara, Yukagaku, 26, 597 (1977) ; F. Szoka, Jr. and D. Papa $=$ hadjopoulos, Ann. Rev. Biophys. Bioeng., 9, 467 (1980) ; Y. Banno and Y. Nozawa, Membrane, 10, 235 (1985).

2) F.B. Finean and R.H. Michell, "New Com= prehensive Biochemistry, Vol. 1: Membrane Structure", Ed., J.B. Finean and R.H. Michell, Elsevier, Amsterdam (1981), p. 22.

3) H. Shimonaka and M. Yamamoto, Membrane, 11, 22 (1986).

4) K. Inoue, Yukagaku, 26, 588 (1977); R. He= rtz, J. Colloid and Interface Sci., 60, 188 (1977) ; K. Beyer and M. Klingenberg, Bios chemistry, 17, 1424 (1978) ; M.L. Jackson, C.F. Schmidt, D. Lichtenberg, B.J. Litman, and A.D. Albert, Biochemistry, 21, 4576
(1982) ; J. Sunamoto, K. Iwamoto, H. Ikeda, and K. Furuse, Chem. Pharm. Bull., 31, 4230 (1983) ; R.J. Robson and E.A. Dennis, Acc. Chem. Res., 16, 251 (1983); M. Ueno, C. Tanford, and J.A. Reynolds, Biochemistry, 23, 3070 (1984) ; W.J. Pjura, A.M. Kleinfeld, and M.J. Kaynovsky, Biochemistry, 23, 2039 (1984).

5) A.D. Bangham, M.M. Standish, and J.C. Watkins, J. Mol. Biol., 13, 238 (1965).

6) J. Seelig, "Spin Labeling: Theory and $A p=$ plications", Ed., L.J. Berliner, Academic, New York (1976), Vol. I .

7) K. Anzai, H. Utsumi, K. Inoue, S. Nojima, and T. Kwan, Chem. Pharm. Bull., 28, 1762 (1980).

8) J. Martinie, J. Michon, and A. Rassat, $J$. Am. Chem. Soc., 97, 1818 (1975).

ESR スピンプローブ法で調ベられた

リポソーム膜と SDS の相互作用

福田 正博・藤津 雅子・大部 一夫

ライオン株式会社 第二応用研究所

（テ132 東京都江戸川区平井 7-13-12）

$50 \mathrm{mM}$ リン酸緩衝液中に抢けるリン脂質りポソーム 膜と SDS の相互作用が ESR スピンプローブ， 2-(3carboxylpropyl)-4,4-dimethyl-2-tridecyl-1,3-oxylを用 いて調べられた。リン脂質二分子膜内 $(13.6 \mathrm{mM})$ に侵 入した SDS 分子 $(2 \mathrm{mM})$ はそれ自身でクラスターを 形成し, 二分子膜の相分離を引き起こすと思われる。こ のような条件下で，二種類のリポソーム，すなわちリン 脂質に富むものと, SDS に富むものが別々に存在する という可能性注心分離による実験で除外された。

\section{国際油脂情報}

々 アメリカの Calgene 社, オランダの会社とカノーラ新種子開発へ

Calgene 社はオランダの主導的な種子会社が開発したなたねの冬型カノーラ品種であるヴァイキングの販売 権を獲得した。この種子は太平洋岸の北西部, 南部および中南部地方で利用されることになろらと同社ではいっ ている。同意契約にはアメリカの根拠地と L. Daehnfeldt A.S. 社との間でアメリカ国内で利用される新しい冬 型品種を開発するために共同研究を行らことも折り込まれている。

\section{ADM 社のカナダ合弁企業, 新しく命名}

ADM Agri-Industries 社は同社の 1 部門として新たに Maple Leaf Monarch の名を採用した。同部門の住 所は 5550 Maplewood Dr., Box 7128, Windsor, Ontario N 9 C 3 Z 1, Canada となっている。 